10.4274/tjps.04657

Research Article

\title{
EFFECTS OF PROBUCOL ON CELL PROLIFERATION IN LEUKEMIA, MULTIPLE MYELOMA, LYMPHOMA AND FIBROBLAST CELL LINES
}

\author{
Probukol'ün lösemi, multipl miyeloma, lenfoma ve fibroblast hücre serilerinde hücre \\ proliferasyonu üzerindeki etkileri
}

Asl1 Koc, Arzu Zeynep Karabay, Ali Yaprak, Zeliha Buyukbingol, Fugen Aktan

Ankara Universtiy, Faculty of Pharmacy, Department of Biochemistry, Ankara, Turkey

\section{ÖZ}

GİRIŞ ve AMAÇ: Probukol, antiiflamatuar, antilipidemik ve antidiyabetik aktivitelere sahip bisfenol bir antioksidandır. Kanser gelişimi ve ilerlemesi kronik inflamasyon ve oksidatif stres ile yakından ilişkilidir ve bu olguları hedefleyen ajanların kanser hücre proliferasyonunu modüle ettikleri gösterilmiştir. Bu bağlamda, bu çalışmada, probukolün farklı kanser hücre serilerinin proliferasyonu üzerindeki etkileri araştırılmıştır

YÖNTEM ve GEREÇLER: Probukolün farklı konsantrasyonlarında hazırlanan çözeltileri kullanılarak K562S (Imatinib duyarıl1), K562R (Imatinib direncli) kronik miyeloid lösemi, U937 histiositik lenfoma, HL60 akut miyeloid lösemi, U266 multipl miyeloma ve L929 fibroblast hücre serilerinde hücre canlılığı MTT testi ile belirlenmiştir.

BULGULAR: Probukol uygulaması $(0.1 \mu \mathrm{M}-10 \mu \mathrm{M})$, K562S, K562R kronik miyeolid lösemi, U937 histositik lenfoma, HL60 akut miyeloid lösemi, U266, H929, RPMI8226 multipl miyelom ve L929 fibroblast hücre serilerinde anlamı bir etki göstermemiştir. Diğer taraftan, probukol uygulaması, H929 ve RPMI8226 hücre serilerinin canlılığını sirasıyla 0.5-10 $\mu \mathrm{M}$ and 5-10 $\mu \mathrm{M}$ konsantrasyon aralığinda anlamlı olarak azaltmıştır $(\mathrm{p}<0.05)$.

TARTIŞMA ve SONUÇ: Probukol uygulaması H929 ve RPMI8226 multipl miyelom hücre serilerinin canlılığını anlamlı olarak inhibe etmiștir. Fakat, probukolün bu etkisi potent bulunmamıștır ve uygulanan konsantrasyon aralığında, hücre canlılığında \% 50 ve üzerinde azalma sergilemediği belirlenmiştir.

Anahtar Kelimeler: Probukol, kronik miyeloid lösemi, multipl miyelom, histositik lenfoma, akut miyeloid lösemi

INTRODUCTION: Probucol is a bis-phenol antioxidant with antiinflammatory, antilipidemic and antidiabetic activites. Development and progression of cancer is closely linked with chronic inflammation and oxidative stress and agents target these processes have been shown to modulate cancer cell proliferation. In this regard, effects of probucol on proliferation of different cancer cell lines was investigated in this study.

METHODS: Different concentrations of probucol solutions were prepared and applied to K 562S (Imatinib sensitive), K562R (Imatinib resistant) chronic myeloid leukemia, U937 histiocytic lymphoma, HL60 acute myeloid leukemia, U266, H929, RPMI8226 multiple myeloma and L929 fibroblast cell lines before determining cell viability with MTT test. RESULTS: Probucol treatment $(0.1 \mu \mathrm{M}-10 \mu \mathrm{M})$ did not exhibit significant toxicity in K562S, K562R chronic myeloid leukemia, U937 histiocytic lymphoma, HL60 acute myeloid leukemia, U266 multiple myeloma and L929 fibroblast cell lines. On the other hand, probucol treatment significantly inhibited H929 and RPMI8226 multiple myeloma cell viability at 0.5- 
$10 \mu \mathrm{M}$ and 5-10 $\mu \mathrm{M}$ concentration ranges respectively.

DISCUSSION AND CONCLUSION: Probucol treatment inhibited cell viability slightly but significantly in H929 and RPMI8226 multiple myeloma cell lines. However, its effect was not found to be potent since $50 \%$ diminishment in cell viability could not be achieved with the applied concentration range of probucol.

Keywords: Probucol, chronic myeloid leukemia, multiple myeloma, histiocytic lymphoma, acute myeloid leukemia

Aslı Koç, Ankara Universtiy, Faculty of Pharmacy, Department of Biochemistry, Ankara, Turkey

aslikoc79@gmail.com

0000-0002-4679-9079

$+905054032096$

25.10.2019

16.12 .2019

\section{INTRODUCTION}

Probucol is a bis-phenol which was originally synthesised as an antioxidant compound with antilipidemic activity. ${ }^{1},{ }^{2}$ Probucol was shown to inhibit oxidation of low density lipoprotein and lower the level of cholesterol in the bloodstream by increasing LDL catabolism rate. ${ }^{3}$ Even if probucol has been used as a lipid-lowering drug for a long time in Japan, its reducing effect on serum HDL-cholesterol (HDL-C) has been found as a drawback which limited its use in western countries. ${ }^{4}$ However its effects are still revisited and various research studies aim to enlighten the effects and pleiotropic functions of this drug. According to these studies, probucol has been shown to inhibit neurovascular inflammation as a single agent, ${ }^{5}$ inhibit atherosclerosis in its combination with atorvastatin, ${ }^{6}$ exert beneficial effects on cognitive functions ${ }^{7}$ and exhibit neuroprotection in in vivo animal models of Parkinson's ${ }^{8}$ and Huntington's diseases. ${ }^{9}$ Anti-inflammatory beta cell protective effect ${ }^{10}$ and NFkB inhibitory activity in spinal cord inflammation ${ }^{11}$ have also been postulated for probucol which refer to inhibition of inflammation by this drug.

Oxidative stress and chronical inflammation are among the characteristic features of neoplastic diseases. Overproduction of reactive oxygen species (ROS) within the cell plays a major role in signaling pathways leading to the initiation and progression of cancer and possible drug resistance ${ }^{12}$. On the other hand, some research studies contrarily showed that increasing oxidative stress may aid in eliminating cancer ${ }^{13}$. Type, stage, oxygen dependence and metastasis and angiogenesis status under hypoxia are among the determinants of cancer cell viability modulation by oxidative stress ${ }^{14}$. Therefore, targeting oxidative stress may be used in cancer therapy and treatment of cancer cells with antioxidants or oxidative stress inducing agents have widely been examined in different research studies. In the literature, a wide range of antioxidant compounds such as NAC, ${ }^{15}$ Vitamin $\mathrm{E},{ }^{16} \mathrm{EGCG},{ }^{17}$ Vitamin $\mathrm{C}^{18}$ and curcumin ${ }^{19}$ have been examined for their potential cancer preventive activities. Antioxidants including ascorbic acid, naringenin and curcumin were shown to induce apoptosis in K562 chronic myeloid leukemia and HL60 acute myeloid leukemia cells. ${ }^{20}$ Another antioxidant compound resveratrol was shown to inhibit proliferation, migration and invasion of U266 multiple myeloma cells ${ }^{21}$ whereas the antioxidant and anti-inflammatory compound quercetin 
was found to inhibit RPMI8226 multiple myeloma cell proliferation by inducing cell cycle arrest and apoptosis ${ }^{22}$.

In light of these research findings, in this study, we aimed to analyze the effects of Probucol which is a known antioxidant and antiinflammatory agent on cell viability in K562S, K562R chronic myeloid leukemia, U937 histiocytic lymphoma, HL60 acute myeloid leukemia, U266 multipl myeloma and L929 fibroblast cell lines.

\section{MATERIALS AND METHODS}

\section{Cell Culture}

Human multiple myeloma cell lines H929, U266 and RPMI 8226, human chronic myeloid leukemia cell line (K562), human histiocytic lymphoma cell line (U937), human acute myeloid leukemia cell line (HL60), mouse fibroblast cell line (L929) were grown in RPMI1640 (Sigma) cell culture medium including \%10 heat inactivated fetal bovine serum, Lglutamine $(2 \mathrm{mmol} / \mathrm{L}), 100 \mathrm{U} / \mathrm{mL}$ penicillin, $100 \mu \mathrm{g} / \mathrm{mL}$ streptomycin. Cells were incubated at $37{ }^{\circ} \mathrm{C}$ incubator with $5 \% \mathrm{CO}_{2}$ and $95 \%$ humidity. Adherent $\mathrm{L} 929$ cells were passaged with trypsinization when they were $80 \%$ confluent.

Imatinib resistant $\mathrm{K} 562$ cell line

K562R cells which are resistant to $5 \mu \mathrm{M}$ imatinib were use in our experiments. $0.6 \mu \mathrm{M}$ imatinib resistant cells were kindly provided by Prof. Carlo Gambacorti-Passerini from University of Milano-Bicocca, Monza, Italy and then imatinib resistance of the cells was increased to $5 \mu \mathrm{M}$ by incubating cells with increasing concentration of imatinib in time. ${ }^{23}$ Cell Viability

To test the effect of probucol on various human cancer cell lines and mouse fibroblast cells, 3(4,5-Dimethylthiazol-2-yl)-2,5-diphenyltetrazolium bromide (MTT) assay was performed. For this purpose, cells (20.000 cells/well) were seeded to 96 well plates. $20 \mathrm{mM}$ stock solution of probucol was pepared by dissolving in DMSO and further dilutions were prepared by culture medium. Maximum concentration of probucol applied to cells was $10 \mu \mathrm{M}$ due to low solubility of compound at higher concentrations. H929, U266, RPMI8226, U937, HL60 cells were treated with $0.1-10 \mu \mathrm{M}$ probucol for $72 \mathrm{~h}$ at $37^{\circ} \mathrm{C}$. Control cells were incubated with same concentration of DMSO as probucol treated cells and DMSO concentration never exceeded $0.5 \%$. For each cell line, the same protocol was used. K562S (Imatinib sensitive) and K562 $\mathrm{R}$ (Imatinib resistant) cells were treated with probucol $(0.1-10 \mu \mathrm{M})$, imatinib and imatinib/probuc 1 combination for $72 \mathrm{~h}$. Imatinib concentrations used for K562S and K562R cells were $0,5 \mu \mathrm{M}$ and $20 \mu \mathrm{M}$ respectively. Since imatinib is a first line therapy option for $\mathrm{CML}$, it was used for determining its single effects or combinational effects probucol. Effect of probucol was also detemined in non-cancerous L929 fibroblast cell line. After proper incubation, MTT solution $(5 \mathrm{mg} / \mathrm{ml})$ was prepared with PBS and cells were incubated with MTT solution for $4 \mathrm{hr}$. Insoluble formazan crystals were dissolved by SDS-HCl solution. Absorbance at $550 \mathrm{~nm}$ was measured by microplate reader (Molecular Devices-Spectra Max spectrophotometer, Sunnyvale, CA, USA).

Statistical Anaylsis

One Way Anova Variance Analysis Test and Tukey post hoc test was performed by Statistixl Software (Nedlands, Western Australia, 6009). All values are represented as mean \pm standart deviation. Significance level of $\mathrm{p}<0.05$ was regarded as statistically significant.

\section{RESULTS}


According to our experiments, probucol significantly decreased cell viability of $\mathrm{H} 929$ and RPMI8226 cell lines between $0.5-10 \mu \mathrm{M}$ and 5-10 $\mu \mathrm{M}$ concentration ranges respectively. On the other hand, we couldn't find any antiproliferative effect on the other cell lines (Figure 1).

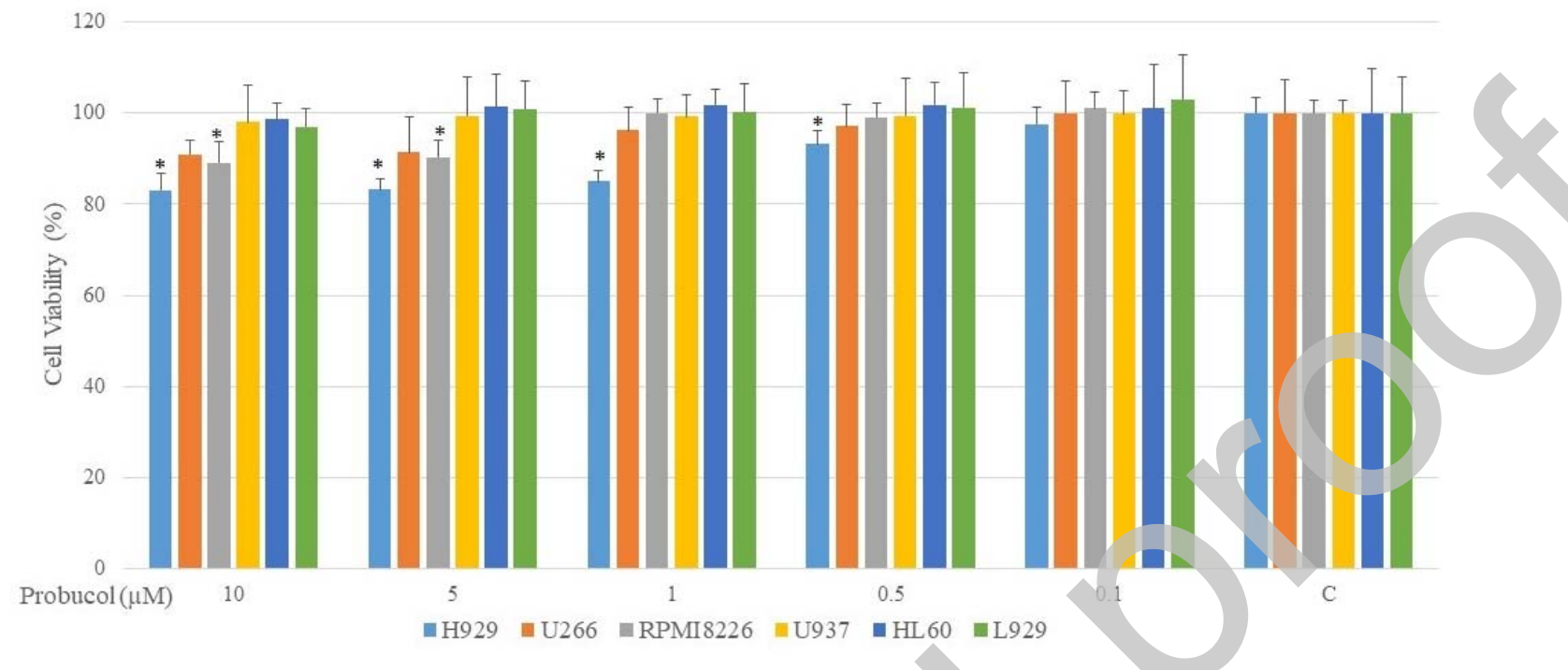

Figure 1. Human multiple myeloma cell lines (H929, U266 and RPMI 8226), human histiocytic lymphoma cell line (U937), human acute myeloid leukemia cell line (HL60) and mouse fibroblast cell line (L929) were treated with $0.1-10 \mu \mathrm{M}$ probucol and cell viability was determined by MTT assay.

$* \mathrm{p}<0.05$ represents the significant differences between control and probucol treated groups. Probucol significantly decreased cell viability of $\mathrm{H} 929$ and RPMI8226 cell lines between 0.5$10 \mu \mathrm{M}$ and $5-10 \mu \mathrm{M}$ concentration ranges respectively.

Due to our earlier results, we used $0.5 \mu \mathrm{M}$ and $20 \mu \mathrm{M}$ imatinib concentrations for $\mathrm{K} 562 \mathrm{~S}$ and K562 R cells respectively which are the known cytotoxic concentrations of imatinib for these cells. When the cells were treated with imatinib alone, it significantly decreased the cell viability of K562S and K562R cells to $36.92 \pm 3.44 \%$ and $48.02 \pm 1.55 \%$ respectively $(p<0.001)$. On the other hand, probucol did not exhibit an antiproliferative effect on both cell lines either as a single agent or in combination with imatinib (Figure 2 and 3). 


\section{0}

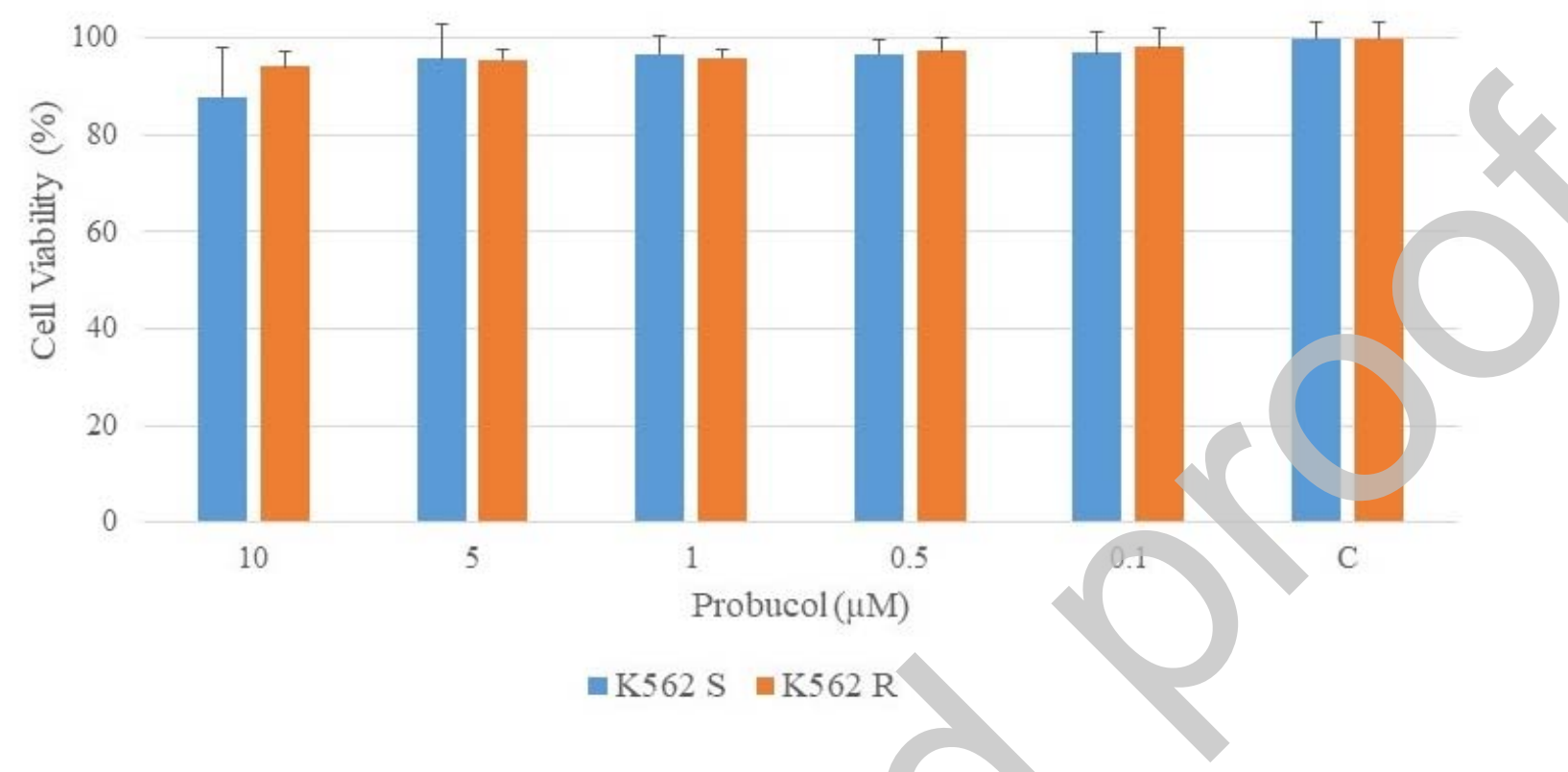

Figure 2. Imatinib sensitive and resistant human chronic myeloid leukemia cell lines (K562S and K562 R) were treated with probucol $(0.1-10 \mu \mathrm{M})$. Cell viability was tested by MTT assay. Probucol did not effect cell viability significantly.

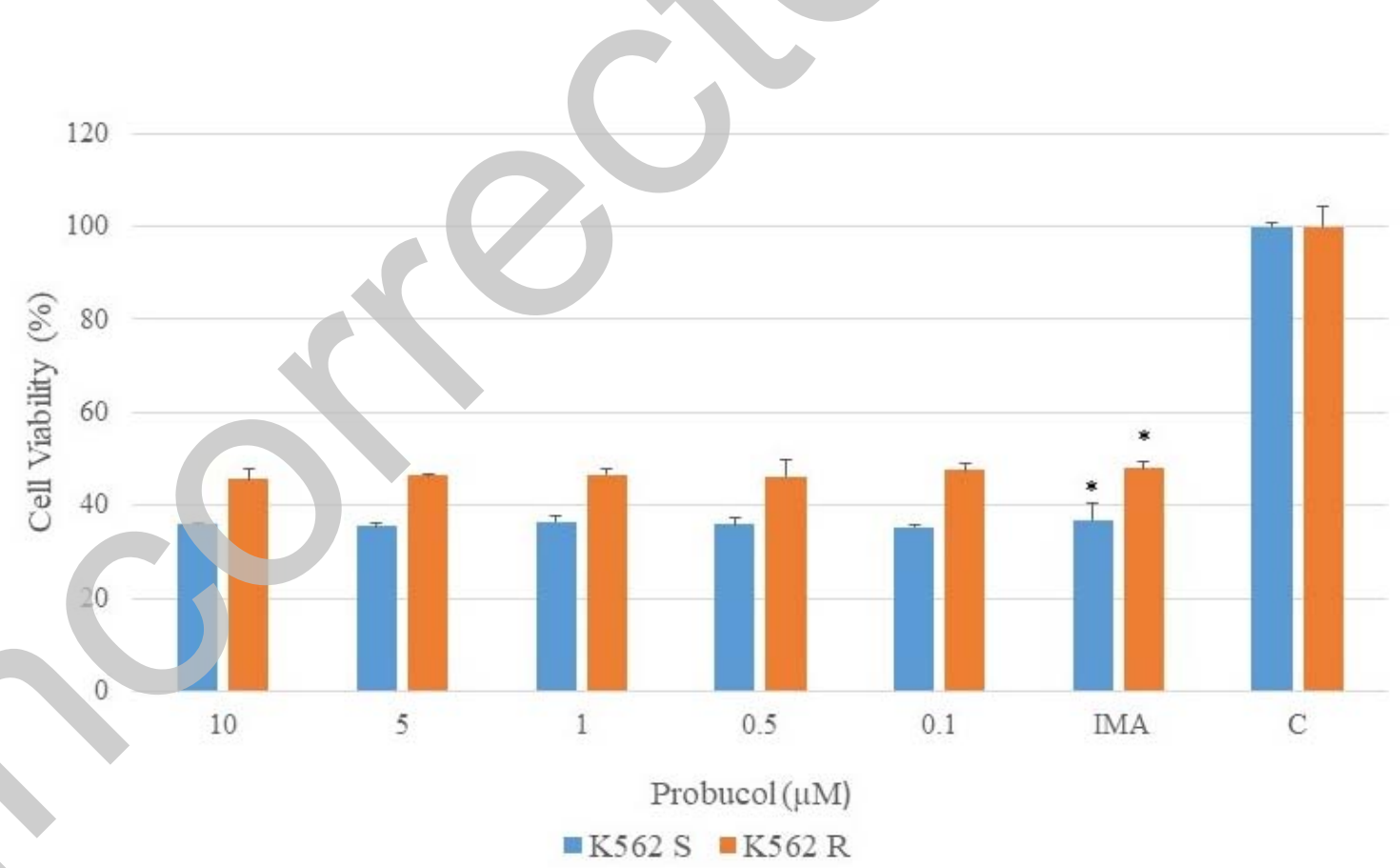

Figure 3. Imatinib sensitive and resistant human chronic myeloid leukemia cell lines (K562S and K562 R) were treated with probucol $(0.1-10 \mu \mathrm{M})$, imatinib $(0.5 \mu \mathrm{M}$ for K562 S cells, 20 $\mu \mathrm{M}$ for K562 R cells) or probucol/imatinib combination. Imatinib treatment decreased cell viability in both $\mathrm{K} 562 \mathrm{~S}$ and $\mathrm{K} 562 \mathrm{R}$ cells significantly * $\mathrm{p}<0.05$ represents the significant differences between control and imatinib only treated groups. Cell viability in imatinib 
probucol combination treated cells also decresed compared to control cells. No significant difference was found between imatinib and imatinib probucol combination treatment in both K562S and K562R cells.

\section{DISCUSSION}

In the literature there are various studies investigating the efficiency of probucol treatment in cancer. In one of these studies, directed nanoassembly formulation of probucol was tested and it was shown to suppress lung metastasis of breast cancer ${ }^{24}$ and in another study it inhibited benzopyrene induced lung tumorigenesis ${ }^{25}$.In addition, probucol was reported to induce antiproliferative effects via inhibition of cell cycle progression and inactivation of NF- $\kappa \mathrm{B}$ and MAPK pathways in human ovarian cancer cells ${ }^{26}$. Probucol was also reported to exert chemopreventive effect in kidney cancer ${ }^{27}$ and probucol treatment of KB cells xen grafts mice had a significant anticancer effect by anti-angiogenic and apoptosis inducing mechanisms ${ }^{28}$. In our knowledge, this is the first study investigating the effects of probucol on K562S, K562R chronic myeloid leukemia, U266, H929 and RPMI8226 multipl myeloma and L929 fibroblast cell lines. Contrary to the research studies which reported diminished cancer cell proliferation by probucol treatment, we did not find potent inhibition of cancer cell viability with $0.1-10 \mu \mathrm{M}$ probucol treatment in any of the cell lines tested. Probucol treatment significantly inhibited H929 and RPMI8226 multiple myeloma cell viability at $0.5-10 \mu \mathrm{M}$ and 5-10 $\mu \mathrm{M}$ concentration ranges respectively. However the percentage of cell viability in these cell lines was still higher than $80 \%$ with probucol treatment and $50 \%$ and higher cell viability inhibition could not be achieved with the applied concentrations of probucol. According to our results probucol did not significantly effect U937 cell viability. In the literature, probucol was tested on U937 cells in various studies. However these studies mostly aimed to reveal its effects on atherosclerosis ${ }^{29}$. In one of these studies, in parallel to our findings, U937 cell viability was reported to be greater than $90 \%$ after incubation with $5 \mathrm{uM}$ probucol$^{30}$.

\section{CONCLUSION}

In conclusion, our results collectively show that probucol was not effective for inducing cell death as a single agent in U937 histiocytic lymphoma, HL60 acute myeloid leukemia and U266 multiple myeloma cell lines. Even if probucol significantly inhibited H929 and RPMI8226 cell proliferation at particular doses, its effects were not potent. Its combination with imatinib also did not change cell viability in K562S and K562R cells which shows its ineffectiveness as a combinational therapy agent in chronic myeloid leukemia.

\section{ACKNOWLED GEMENT}

This study was supported by Scientific Research Projects (BAP) of Ankara University (16L0237007).

Conflict of Interest: No conflict of interest was declared by the authors

\section{REFERENCES}

1. Heel RC, RN Brogden, TM Speight, GS Avery. Probucol: a review of its pharmacological properties and therapeutic use in patients with hypercholesterolaemia. Drugs.1978; 15:409428.

2. Buckley MM, KL Goa, AH Price, RN Brogden. Probucol. A reappraisal of its pharmacological properties and therapeutic use in hypercholesterolaemia. Drugs.1989; 37:761-800.

3. Parthasarathy S, SG Young, JL Witztum, RC Pittman, D Steinberg. Probucol inhibits oxidative modification of low density lipoprotein. The Journal of clinical investigation.1986; 77:641-644. 
4. Yamashita S, D Masuda, Y Matsuzawa. Did we abandon probucol too soon? Current opinion in lipidology.2015; 26:304-316.

5. Takechi R, MM Pallebage-Gamarallage, V Lam, C Giles, JC Mamo. Long-term probucol therapy continues to suppress markers of neurovascular inflammation in a dietary induced model of cerebral capillary dysfunction. Lipids in health and disease.2014; 13:91.

6. Keyamura Y, C Nagano, M Kohashi, M Niimi, M Nozako, T Koyama, R Yasufuku, A Imaizumi, H Itabe, T Yoshikawa. Add-on effect of probucol in atherosclerotic, cholesterol-fed rabbits treated with atorvastatin. PloS one.2014; 9:e96929.

7. Mamo JC, V Lam, E Brook, A Mooranian, H Al-Salami, N Fimognari, M Nesbit, R Takechi. Probucol prevents blood-brain barrier dysfunction and cognitive decline in mice maintained on pro-diabetic diet. Diabetes \& vascular disease research.2019; 16:87-97 8. Ribeiro RP, EL Moreira, DB Santos, D Colle, AA Dos Santos, KC Peres, CP Fiqueiredo M Farina. Probucol affords neuroprotection in a 6-OHDA mouse model of Parkinson's disease. Neurochemical research.2013; 38:660-668.

9. Colle D, DB Santos, EL Moreira, JM Hartwig, AA dos Santos, LT Zimmermann, MA Hort, M Farina. Probucol increases striatal glutathione peroxidase activity and protects against 3-nitropropionic acid-induced pro-oxidative damage in rats. PloS one.2013; 8:e67658. 10. Mooranian A, N Zamani, G Luna, H Al-Sallami, M Mikov, S Golocorbin-Kon, G Stojanovic, F Arfuso, B Kovacevic, H Al-Salami. Bile acid-polymer-probucol microparticles: protective effect on pancreatic beta-cells and decrease in type 1 diabetes development in a murine model. Pharmaceutical development and technology.2019; 1-6.

11. Zucoloto AZ, MF Manchope, SM Borghi, TS Dos Santos, V Fattori, S Badaro-Garcia, D Camilios-Neto, R Casagrande, WA Verri, Jr. Probucol Ameliorates Complete Freund's Adjuvant-Induced Hyperalgesia by Targeting Peripheral and Spinal Cord Inflammation. Inflammation.2019; 42:1474-1490.

12. Snezhkina AV, AV Kudryavtseva, OL Kardymon, MV Savvateeva, NV Melnikova, GS Krasnov, AA Dmitriev. ROS Generation and Antioxidant Defense Systems in Normal and Malignant Cells. Oxidative medicine and cellular longevity.2019; 2019:6175804.

13. Hanikoglu A, H Ozben, F Hanikoglu, T Ozben. Hybrid Compounds \& Oxidative Stress Induced Apoptosis In Cancer Therapy. Current medicinal chemistry.2018;

14. Udensi UK, PB Tchounwou. Dual effect of oxidative stress on leukemia cancer induction and treatment. Journal of experimental \& clinical cancer research : CR.2014; 33:106.

15. Agarwal A, U Munoz-Najar, U Klueh, SC Shih, KP Claffey. N-acetyl-cysteine promotes angiostatin production and vascular collapse in an orthotopic model of breast cancer. The American journal of pathology.2004; 164:1683-1696.

16. Fontana F, RM Moretti, M Raimondi, M Marzagalli, G Beretta, P Procacci, P Sartori, M Montagnani Mare11i, P Limonta. delta-Tocotrienol induces apoptosis, involving endoplasmic reticulum stress and autophagy, and paraptosis in prostate cancer cells. Cell proliferation.2019; 52:e12576.

17. Zan L, Q Chen, L Zhang, X Li. Epigallocatechin gallate (EGCG) suppresses growth and tumorigenicity in breast cancer cells by downregulation of miR-25. Bioengineered.2019; 10:374-382.

18. Zeng LH, QM Wang, LY Feng, YD Ke, QZ Xu, AY Wei, C Zhang, RB Ying. High-dose vitamin $C$ suppresses the invasion and metastasis of breast cancer cells via inhibiting epithelial-mesenchymal transition. OncoTargets and therapy.2019; 12:7405-7413.

19. Sun C, S Zhang, C Liu, X Liu. Curcumin Promoted miR-34a Expression and Suppressed Proliferation of Gastric Cancer Cells. Cancer biotherapy \& radiopharmaceuticals.2019; 20. ASarkar R, A Mukherjee, S Mukherjee, R Biswas, J Biswas, M Roy. Curcumin augments the efficacy of antitumor drugs used in leukemia by modulation of heat shock proteins via HDAC6. Journal of environmental pathology, toxicology and oncology : official organ of the 
International Society for Environmental Toxicology and Cancer.2014; 33:247-263;

BMastrangelo D, L Massai, F Lo Coco, NI Noguera, L Borgia, G Fioritoni, A Berardi, A Iacone, M Muscettola, E Pelosi, G Castelli, U Testa, F Di Pisa, G Grasso. Cytotoxic effects of high concentrations of sodium ascorbate on human myeloid cell lines. Annals of hematology.2015; 94:1807-1816; CLi RF, YQ Feng, JH Chen, LT Ge, SY Xiao, XL Zuo. Naringenin suppresses K562 human leukemia cell proliferation and ameliorates Adriamycininduced oxidative damage in polymorphonuclear leukocytes. Experimental and therapeutic medicine.2015; 9:697-706.

21. Geng W, X Guo, L Zhang, Y Ma, L Wang, Z Liu, H Ji, Y Xiong. Resveratrol inhibits proliferation, migration and invasion of multiple myeloma cells via NEAT1-mediated Wnt/beta-catenin signaling pathway. Biomedicine $\&$ pharmacotherapy $=$ Biomedecine $\&$ pharmacotherapie.2018; 107:484-494.

22. Najibi A, R Heidari, J Zarifi, A Jamshidzadeh, N Firoozabadi, H Niknahad. Evaluating the Role of Drug Metabolism and Reactive Intermediates in Trazodone-Induced Cytotoxicity toward Freshly-Isolated Rat Hepatocytes. Drug research.2016; 66:592-596.

23. Hekmatshoar Y, T Ozkan, B Altinok Gunes, S Bozkurt, A Karadag, AZ Karabay, A Sunguroglu. Characterization of imatinib-resistant K562 cell line displaying resistance mechanisms. Cellular and molecular biology (Noisy-le-Grand, France).2018; 64:23-30. 24. Zhang Z, H Cao, S Jiang, Z Liu, X He, H Yu, Y Li. Nanoassembly of probucol enables novel therapeutic efficacy in the suppression of lung metastasis of breast cancer. Small (Weinheim an der Bergstrasse, Germany).2014; 10:4735-4745.

25. Zarkovic M, X Qin, Y Nakatsuru, S Zhang, Y Yamazaki, H Oda, T Ishikawa, T Ishikawa. Inhibitory effect of probucol on benzo[a]pyrene induced lung tumorigenesis.

Carcinogenesis. 1995; 16:2599-2601.

26. Chuang LY, JY Guh, YL Ye, YH Lee, JS Huang. Effects of probucol on cell proliferation in human ovarian cancer cells. Toxicology research 2016; 5:331-339.

27. Iqbal M, Y Okazaki, S Okada. Probucol modulates iron nitrilotriacetate (Fe-NTA)dependent renal carcinogenesis and hyperproliferative response: diminution of oxidative stress. Molecular and cellular biochemistry.2007; 304:61-69.

28. Nishimura G, S Yanoma, H Mizuno, K Kawakami, M Tsukuda. An antioxidant, probucol, induces anti-angiogenesis and apoptosis in athymic nude mouse xenografted human head and neck squamous carcinoma cells. Japanese journal of cancer research : Gann. 1999; 90:12241230.

29. Kaneko M, J Hayashi, I Saito, N Miyasaka. Probucol downregulates E-selectin expression on cultured human vascular endothelial cells. Arteriosclerosis, thrombosis, and vascular biology.1996; 16:1047-1051.

30. Chen J-W, Y-H Chen, F-Y Lin, Y-L Chen, S-J Lin. Ginkgo biloba extract inhibits tumor necrosis actor- $\alpha$-induced reactive oxygen species generation, transcription factor activation, and cell adhesion molecule expression in human aortic endothelial cells. Arteriosclerosis, thrombosis, and vascular biology.2003; 23:1559-1566. 